\title{
Differential abundance analysis of mesocarp protein from high- and low- yielding oil palms associates non-oil biosynthetic enzymes to lipid biosynthesis
}

\author{
Tony Eng Keong Ooi ${ }^{1 *}$ D, Wan Chin Yeap ${ }^{1}$, Leona Daniela Jeffery Daim¹, Boon Zean Ng², Fong Chin Lee ${ }^{1}$, \\ Ainul Masni Othman', David Ross Appleton ${ }^{1}$, Fook Tim Chew ${ }^{3}$ and Harikrishna Kulaveerasingam ${ }^{1}$
}

\begin{abstract}
Background: The oil palm Elaeis guineensis Jacq. which produces the highest yield per unit land area of the oil crops is the most important commercial oil crop in South East Asia. The fleshy mesocarp of oil palm fruit, where oil is mostly derived from, contains up to $90 \%$ dry weight of oil (one of the most concentrated in plant tissues). Hence, there is attention given to gain insights into the processes of oil deposition in this oil rich tissue. For that purpose, two-dimensional differential gel electrophoresis (DIGE) coupled with western assays, were used here to analyze differential protein levels in genetically-related high-and low-yielding oil palm mesocarps.

Results: From the DIGE comparative analysis in combination with western analysis, 41 unique differentially accumulated proteins were discovered. Functional categorization of these proteins placed them in the metabolisms of lipid, carbohydrate, amino acids, energy, structural proteins, as well as in other functions. In particular, higher abundance of fructose-1,6-biphosphate aldolase combined with reduced level of triosephosphate isomerase and glyceraldehyde-3-phosphate dehydrogenase may be indicative of important flux balance changes in glycolysis, while amino acid metabolism also appeared to be closely linked with oil yield.

Conclusions: Forty-one proteins in several important biological pathways were identified as exhibiting differential in abundance at critical oil production stages. These confirm that oil yield is a complex trait involving the regulation of genes in multiple biological pathways. The results also provide insights into key control points of lipid biosynthesis in oil palm and can assist in the development of genetic markers for use in oil palm breeding programmes.
\end{abstract}

Keywords: Oil palm, Elaeis guineensis, Yield, Lipid biosynthesis, Plant proteome

\section{Background}

The oil palm Elaeis guineensis Jacq. produces the highest yield per unit land area of the oil crops [1] and has become the most important commercial oil crop in tropical South East Asia. The oil palm fruit is a drupe with bunches containing 1000-3000 fruitlets and most of the commercially extracted oil is derived from its fleshly mesocarp. The mesocarp contains up to $90 \%$ dry weight of oil, one of the most concentrated found in plant

\footnotetext{
* Correspondence: tony.ooi.engkeong@simedarby.com

${ }^{1}$ Sime Darby Technology Centre Sdn. Bhd., UPM-MTDC Technology Centre III, Lebuh Silikon, Universiti Putra Malaysia, 1st Floor, Block B, 43400 Serdang,

Selangor, Malaysia

Full list of author information is available at the end of the article
}

tissues $[2,3]$. Yield remains the main focus in oil palm cultivation due to the limitation of available arable land and growing demand for edible and non-edible oils. Current standard commercial oil palm material can produce approximately 4 ton/hectare/year of oil at a planting density of 148 palms/hectare. However, some plants have attained yields greater than 10 ton/hectare/year in trial plots giving an indication of potential future yields.

Recent advances in biochemical analysis have allowed researchers to develop omics techniques to investigate crop traits at a cellular level. In particular, proteomics has been used extensively to investigate the biochemical processes attribute to traits in non-oil crops [4-9], as 
well as processes leading to increased lipid production in oil crops [10-15]. The proteomes of two near-isogenic sunflower varieties differing in seed oil traits were comparatively analyzed by Hajduch et al. [10]. Proteins associated with glycolytic pathway were found highly up-regulated in the high oil variety. In contrast, proteins associated to amino acid biosynthesis were up-regulated in the low oil variety. Another group of researchers, Troncoso-Ponce et al. [11] investigated the glycolytic initial metabolites and enzyme activities from developing seed of two different sunflower lines, of high and low oil content, during storage lipid accumulation. They discovered that the amount of sucrose produced and available for lipid synthesis was higher in high oil line. In addition, the enzymatic activities of both phosphoglycerate kinase and enolase were found notably higher in this line, allowing increased synthesis of phosphoenolpyruvate, an intermediate carbon donor for lipid biosynthesis. Another comparative analysis of the soluble proteins found in early developing germs from high-oil and normal inbred lines in maize [12], revealed that 3 enzymes closely related to lipid biosynthesis, namely enoyl-ACP reductase, stearoyl-ACP desaturase and acetyl-CoA C-acyltransferase, had higher abundance in high-oil lines than in normal.

Recently, several studies that employed comparative transcriptomics and metabolomics to gain insight into the development of oil palm fruit have been reported [16-21]. Bourgis et al. [16] examined the differences in transcriptome and metabolome between oil palm and date palm during mesocarp development, in the hope to elucidate the mechanisms that lead to an extreme difference in carbon partitioning in them (the mesocarp of oil palm accumulates oil while the mesocarp of date palm accumulates sugars). They implicated that synthesis of fatty acids and supply of pyruvate in the plastid, rather than acyl assembly into triacylglcerol, as the main factor for the accumulation of oil in the mesocarp of oil palm. Tranbarger et al. [17] and Dussert et al. [21] investigated the transcriptional basis of lipid accumulation in the mesocarp of oil palm. A transcript, homologous to Arabidopsis seed oil transcription factor WRINKLED1, was identified to coordinate its transcript level with several fatty acids biosynthetic transcripts and high rates of lipid deposition, suggesting the mesocarp homolog is an important regulatory factor in oil biosynthesis.

The DIGE (Difference Gel Electrophoresis) analysis $[22,23]$, a two dimensional gel electrophoresis employing sensitive fluorescent labeling dyes, has been successfully employed in protein expression analyses in rice and sunflower [10, 24]. Although DIGE has been utilized in the studies of quantitative proteomics in these plants, but none in oil palm. In this study, we report the first comparative proteomics analysis of two distinct groups of oil palms (low-yielding, LY palms and high-yielding,
HY palms) using DIGE analysis, followed by confirmation using western blot immunoassays, to identify proteins associated with yield in oil palm and provide insights into the regulation of lipid biosynthesis.

\section{Results and discussion \\ Mesocarp tissue extraction protocol for 2D gel electrophoresis}

Three methods were tested for protein extraction from oil palm mesocarp tissues. They were (i) the sucrose method published by He et al. [25] for pine needles, (ii) a modified sucrose method and (iii) the phenol/ammonium acetate method [26]. The sucrose method was modified in this study to give a better 2D gels, evidently with more protein spots being resolved in the alkaline range (Fig. 1). Moreover, the mean number of protein spots detected in 2D gels (3 replicate gels) produced from the original sucrose method was $576 \pm 18$ spots whilst $738 \pm 80$ spots detected in $2 \mathrm{D}$ gels from the modified sucrose method. Successively, the modified sucrose method was compared to the phenol/ammonium acetate method. In terms of spot resolution and separation, the 2D gels produced from these 2 methods were comparable (Fig. 1) in that $729 \pm 78$ spots were detected from 2D gels of the third method. Consequently, the modified sucrose method was adopted to extract protein from oil palm mesocarp tissues for subsequent 2D gel electrophoresis study. Moreover, the latter method involves the usage of toxic phenol and procedurally lengthy.

\section{Selection of plant materials and comparative studies}

In order to investigate biosynthetic controls leading to significant increases in yield, the proteomes of genetically related oil palms grown in the same field and exhibiting a 2-fold difference in oil yield [19] were selected for this study. Mesocarp samples were collected at three key phases preceding and during lipid biosynthesis: 12 weeks after pollination (WAP) (preceding), 16 WAP (onset of lipid deposition) and 18 WAP [3, 17, 27-29]. The DIGE protein analysis was used to identify pairwise differential proteins between three high-yielding (HY) and three comparatively low-yielding (LY) plants. A total of nine analytical gels were produced (Fig. 2; see all DIGE gels in Additional file 1) from the eighteen samples and subsequently used for cross-gel Biological Variation Analysis (BVA) (DeCyder ${ }^{\text {Tx }}$ 2D software Version 6.5 by Amersham BioSciences): HY versus LY at 12, 16 and 18 WAP, in addition to temporal analysis of HY palms: 16 and 18 WAP versus 12 WAP (Additional file 2). Out of approximately 2000 peptide spots detected, 84 were found to be at least 1.5 -fold different and have a $p$-value $<0.1$. The $p$-value $<0.1$ was taken to compensate the small sample size (only 3 biological replicates) in this DIGE experiment. Moreover, the DIGE experiment here functioned 

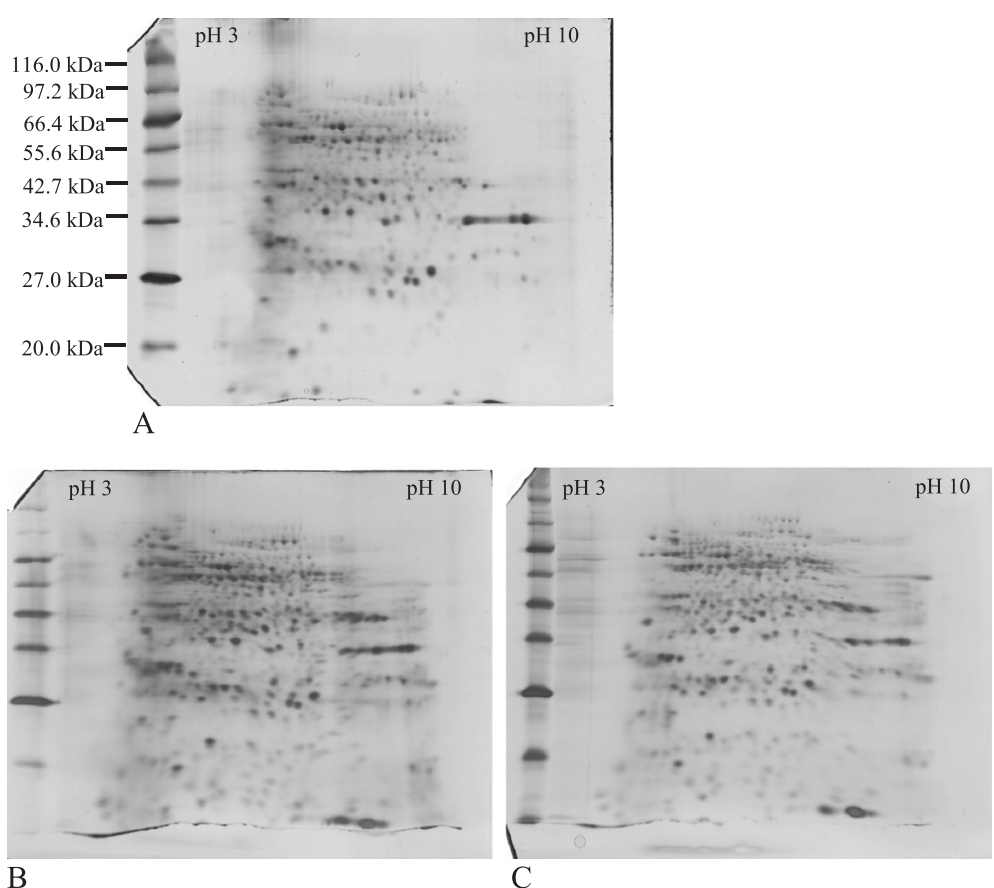

Fig. 1 Evaluation of extraction protocols for 2D gels. Three methods were compared. Silver-stained gels were produced after running IEF for 9 kVh using $7 \mathrm{~cm}$ IEF strips of pH3-10NL, with similar H16WAP samples ( $3 \mu \mathrm{g} / \mathrm{gel})$. Gel B and C are better 2D gels compared to A. Both are comparable. [a: original sucrose method; $\mathbf{b}$ : modified sucrose method; $\mathbf{c}$ : phenol/ammonium acetate method]

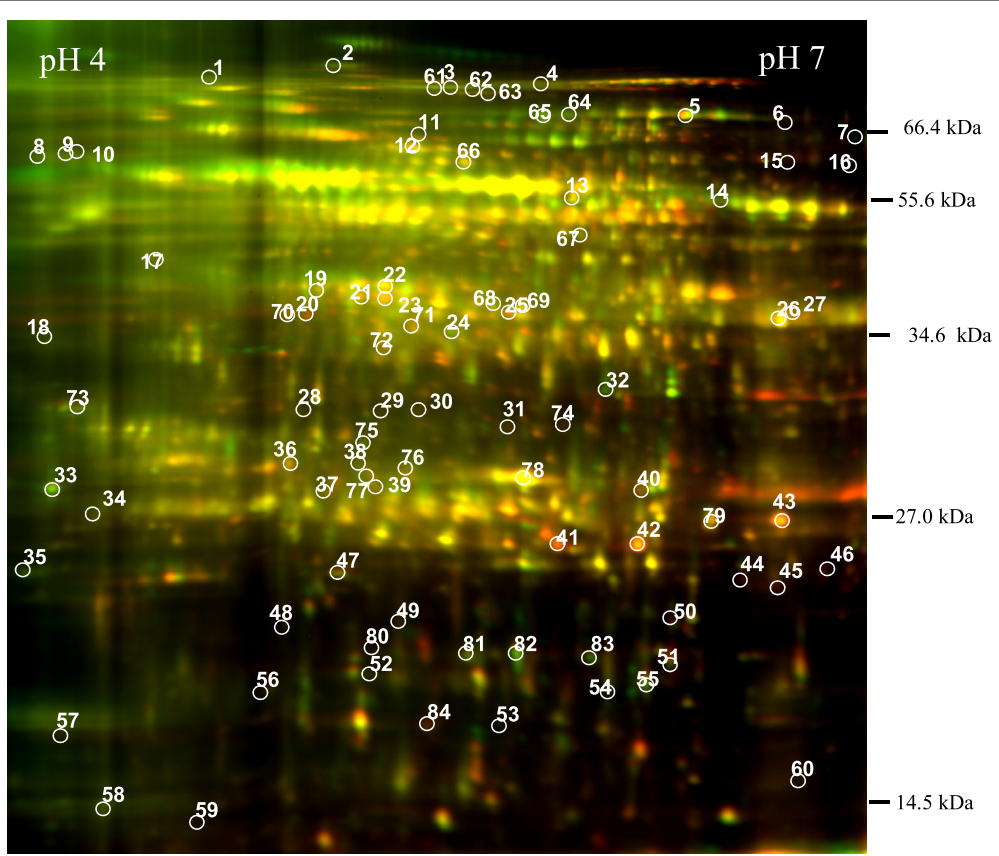

Fig. 2 Overlay of Cy3 and Cy5 gel images of a 2-dimensional DIGE gel. DIGE gels were produced for spot analysis using $13 \mathrm{~cm}$ IEF strips of pH 4-7 with 20-kVh focusing. Mesocarp protein from high yielding palms was labeled with Cy3 whilst mesocarp protein from low yielding palms with Cy5. A total of nine DIGE gels were produced for analysis from three biological replicates of 12,16 and 18 WAP fruit. Numbers in the gel indicate the geographical position of protein spots in the map 
mainly as a screening tool for subsequent western analysis that involved bigger populations. Mass spectrometry identification using MALDI-TOF/TOF was conducted on 61 distinct spots with isoforms removed. Fifty-three protein spots were identified based on combined MS and MS/MS matching to proteins in the public domain of NCBI nonredundant database, of which 45 were unique (see Additional file 3 for MASCOT protein-peptide identification results). Subsequently, the DIGE results were cross-checked with western analysis by using a larger sample size of 8 biological replicates (Figs. 3 and 4, Additional file 4, Additional file 5, Additional file 6, Additional file 7).

The functions of the majority of the differential proteins of those having significant $p$-value $<0.05$ from DIGE and western analyses, a total of 41 proteins, could be grouped into six main categories (Table 1) according to the Kyoto Encyclopedia of Genes and Genomes (KEGG) pathways database [30]: lipid metabolism, carbohydrate metabolism, amino acid metabolism, energy metabolism, stress-related proteins and structure-related proteins. Oil yield is known to be a complex trait involving the regulation of many genes across multiple biological pathways [31]. In this study, only 2 of the 41 proteins are known to be involved in lipid biosynthesis, while the remaining are involved in a range of biosynthetic pathways.

\section{Lipid metabolism}

None of the key enzymes known to be directly involved in lipid biosynthesis or assembly was found to be differential between the HY and LY oil palm samples in this study, for example plastid fatty acid synthase and thioesterase, cytosolic acyl-CoA synthetase and the endoplasmic reticulum located enzymes of the Kennedy pathway $[12,32]$. This could possibly due to the fact that the DIGE experiment here was limited to the detection of proteins within $\mathrm{pH} 4$ to 7 only. The $\mathrm{pH} 4-7$ range was chosen in this study because it is known that the majority of cellular proteins are found in this particular $\mathrm{pH}$ range. The pI of oil palm fatty acid synthases and thioesterases, and acyl-CoA synthetases, as well as the endoplastic reticulum located enzymes of the Kennedy pathway are

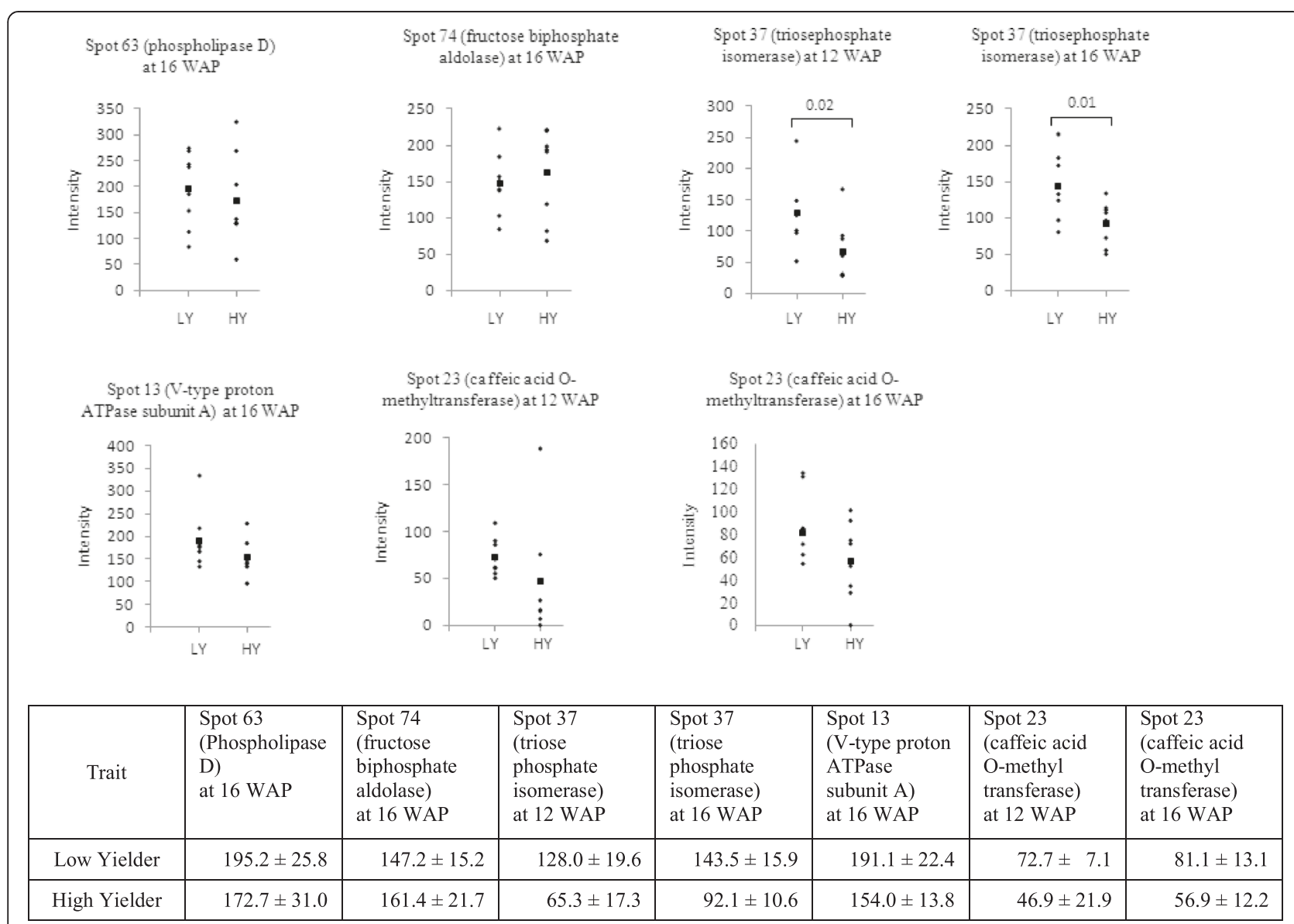

Fig. 3 Enzyme levels in LY and HY palm mesocarp tissues $(n=8)$. Intensity data were generated from dot blot immunoassay using antibodies against the respective enzymes. ( $\mathbf{\square})$ indicates the mean of each group. Significant Student's $t$-test $p$-values are shown. The mean and standard error are given in the accompanying table 


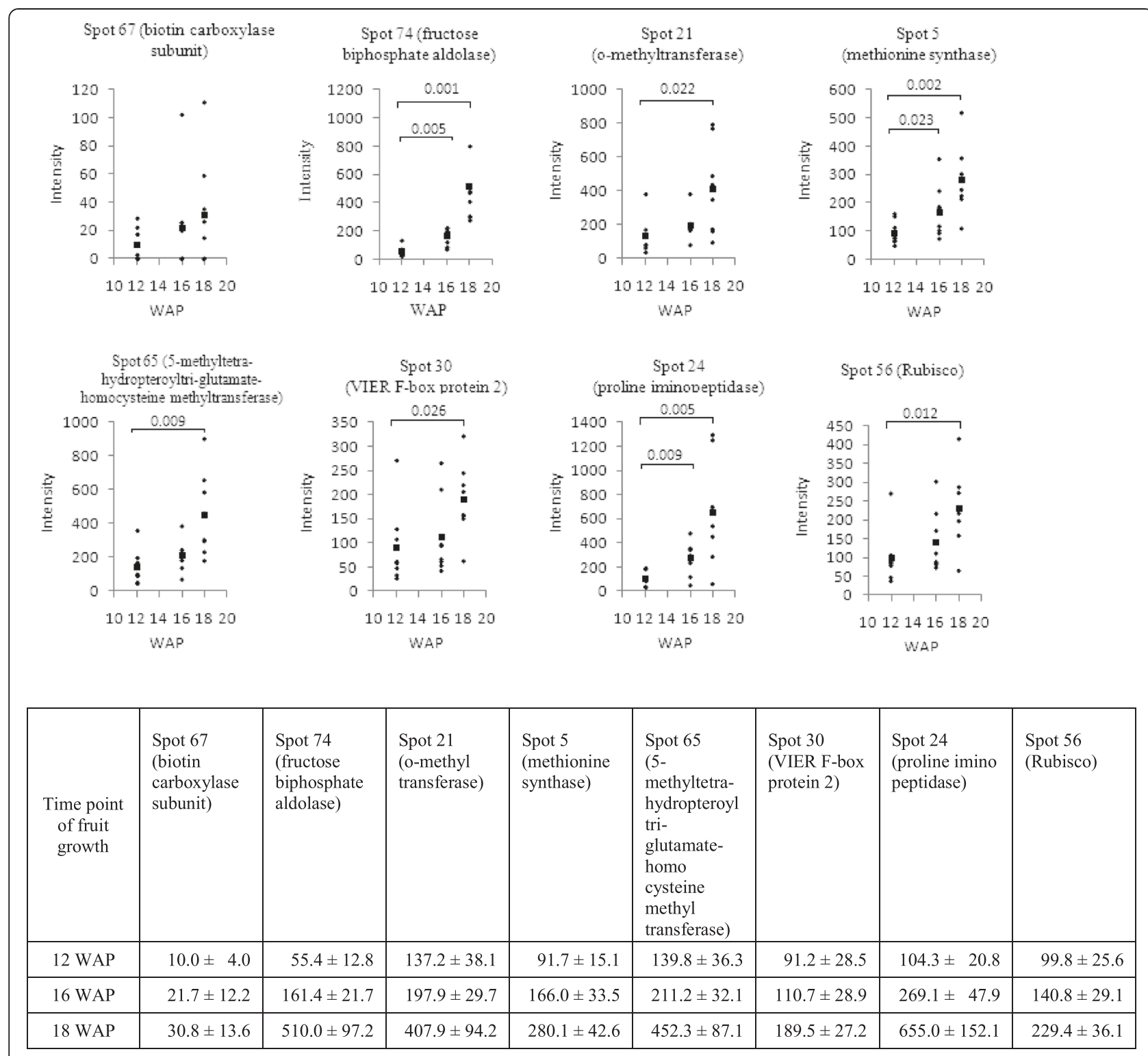

Fig. 4 Temporal level of differential proteins found in HY palm mesocarp tissue during fruit development at 12-18 WAP $(n=8)$. Intensity data were generated from dot blot immunoassay using antibodies against the respective enzymes. (- $\mathbf{m}$ indicates the mean of each group. Significant Student's t-test p-values are shown. The mean and standard error are depicted in the accompanying table

not known. However, several Arabidopsis fatty acid synthases, fatty acid thioesterases and acyl-CoA synthetases were reported to have $\mathrm{pI}$ in the range above 7 [33-38]. Incidentally, the pI of some of the enzymes in the Kennedy pathway, viz the glycerol-3-phosphate $O$ acyltransferase, lysophosphatidic acid acyltransferase and diacylglycerol acyltransferase are reported to be in the alkaline range, respectively, pI 9.36 in flowering plant Echium pitardii [39], pI 9.43 in peanut [40] and pI 9.46 in microalga Myrmecia incisa [41].

Interestingly, the accumulation of phospholipase $\mathrm{D}$ at 16 WAP was observed to be significantly higher [1.6x, $p$ value $<0.05$ ] (Additional file 2 ) in LY palms compared to
HY palms using DIGE (Table 1) and western analysis (Fig. 3). Phospholipase D cleaves the ester bond between the phosphatidyl moiety and the head group of phospholipids, but can also act as a transferase [42-44]. A study by Yu [45] found Arabidopsis phospholipase D knockout mutants exhibited decreased seed oil content compared to wild type, although it is possible that a reduction in the activity of this lipase at the period of highest lipid biosynthesis may be beneficial for yield.

Biotin carboxylase subunit was found to be upregulated in the HY palms during lipid biosynthesis from 1.8-fold at 16 WAP to 3.0-fold at 18 WAP [ $p$-value $<$ 0.05] (Additional file 2) compared to $12 \mathrm{WAP}$ when lipid 
Table 1 Unique proteins expressed differentially in HY versus LY palms at 12-18 WAP, or exhibiting temporal expression differences in HY palms

\begin{tabular}{|c|c|c|c|c|c|c|c|c|c|c|c|c|c|}
\hline \multirow[t]{2}{*}{ Spot \# } & \multirow[t]{2}{*}{ Protein name ${ }^{a}$} & \multirow[t]{2}{*}{ NCBI Accession \# } & \multirow[t]{2}{*}{ Protein MW } & \multirow[t]{2}{*}{ Protein PI } & \multirow[t]{2}{*}{ Pep.Count } & \multirow[t]{2}{*}{$\begin{array}{l}\text { Protein } \\
\text { score }\end{array}$} & \multirow[t]{2}{*}{$\begin{array}{l}\text { Protein } \\
\text { Score C. I. \% }\end{array}$} & \multirow[t]{2}{*}{$\begin{array}{l}\text { Total ion } \\
\text { score }\end{array}$} & \multirow[t]{2}{*}{$\begin{array}{l}\text { Total lon } \\
\text { C. I. } \%\end{array}$} & \multicolumn{2}{|c|}{$\begin{array}{l}\text { Expression } \\
\text { difference HY } \\
\text { versus LY (WAP) }\end{array}$} & \multicolumn{2}{|c|}{$\begin{array}{l}\text { Temporal expression } \\
\text { trend in HY (WAP) }\end{array}$} \\
\hline & & & & & & & & & & $\overline{\mathrm{DIGE}}$ & $\begin{array}{l}\text { Western } \\
\text { analysis }\end{array}$ & $\overline{D I G E}$ & $\begin{array}{l}\text { Western } \\
\text { analysis }\end{array}$ \\
\hline & Lipid metabolism & & & & & & & & & & & & \\
\hline 63 & phospholipase D [Oryza sativa] & gi|1020415 & 92151 & 5.6 & 11 & 130 & 100.0 & 40 & 67.4 & down (16) & down (16) & down (16) & up $(16,18)$ \\
\hline \multirow[t]{2}{*}{67} & $\begin{array}{l}\text { biotin carboxylase subunit } \\
\text { [Glycine max] }\end{array}$ & gi|3219361 & 58770 & 7.2 & 11 & 302 & 100.0 & 222 & 100.0 & - & - & up $(16,18)$ & up $(16,18)$ \\
\hline & Carbohydrate metabolism & & & & & & & & & & & & \\
\hline 26 & $\begin{array}{l}\text { glyceraldehyde 3-phosphate } \\
\text { dehydrogenase [Elaeis guineensis] }\end{array}$ & gi|82400215 & 32136 & 7.1 & 7 & 191 & 100.0 & 122 & 100.0 & down (16) & down $(12,16)$ & - & up (18) \\
\hline 74 & $\begin{array}{l}\text { fructose-biphosphate aldolase } \\
\text { [Elaeis guineensis] }\end{array}$ & gi|192910908 & 38578 & 6.7 & 8 & 174 & 100.0 & 119 & 100.0 & up (16) & up (16) & up $(16,18)$ & up $(16,18)$ \\
\hline \multirow[t]{2}{*}{37} & $\begin{array}{l}\text { Triosephosphate isomerase, } \\
\text { chloroplastic [Secale cereale] }\end{array}$ & gi|1174745 & 31613 & 6.0 & 7 & 103 & 100.0 & 56 & 99.4 & down (16) & down $(12,16)$ & - & up (18) \\
\hline & Energy metabolism & & & & & & & & & & & & \\
\hline 44 & $\begin{array}{l}\text { NADPH:quinone reductase } \\
\text { family protein [Arabidopsis thaliana] }\end{array}$ & gi|30687535 & 21778 & 6.1 & 4 & 185 & 100.0 & 155 & 100.0 & down (12) & nt & up (16) & nt \\
\hline 46 & $\begin{array}{l}\text { FQR1 (flavodoxin-like quinone } \\
\text { reductase 1) [Arabidopsis thaliana] }\end{array}$ & gi|15239652 & 21782 & 6.0 & 4 & 130 & 100.0 & 100 & 100.0 & down (12) & nt & up (16) & nt \\
\hline 75 & $\begin{array}{l}\text { short chain type dehydrogenase } \\
\text { [Ricinus communis] }\end{array}$ & gi|223550344 & 33332 & 9.5 & 3 & 104 & 100.0 & 88 & 100.0 & - & nt & up $(16,18)$ & nt \\
\hline \multirow[t]{2}{*}{51} & $\begin{array}{l}\text { mitochondrial peroxiredoxin } \\
\text { [Pisum sativum] }\end{array}$ & gi|47775654 & 21463 & 8.4 & 3 & 140 & 100.0 & 120 & 100.0 & up (16) & down (16) & up $(16,18)$ & up (18) \\
\hline & Amino acid metabolism & & & & & & & & & & & & \\
\hline 21 & $\begin{array}{l}\text { o-methyltransferase } \\
\text { [Ricinus communis] }\end{array}$ & gi|223540510 & 40000 & 5.3 & 4 & 92 & 100.0 & 68 & 99.9 & down (16) & down (16) & down $(16,18)$ & up (18) \\
\hline 5 & $\begin{array}{l}\text { methionine synthase protein } \\
\text { [Sorghum bicolor] }\end{array}$ & gi|18483235 & 83736 & 5.9 & 12 & 211 & 100.0 & 166 & 100.0 & down (16) & - & - & up $(16,18)$ \\
\hline 65 & $\begin{array}{l}\text { 5-methyltetrahydropteroyltri- } \\
\text { glutamate-homocysteine } \\
\text { methyltransferase [Oryza sativa] }\end{array}$ & gi|108862992 & 84582 & 5.9 & 9 & 84 & 99.7 & 39 & 71.7 & - & - & down $(16,18)$ & up (18) \\
\hline 30 & $\begin{array}{l}\text { VFB2 (VIER F-BOX PROTEINE 2); } \\
\text { ubiquitin-protein ligase } \\
\text { [Arabidopsis thaliana] }\end{array}$ & gi|18409012 & 57212 & 8.7 & 8 & 65 & 80.5 & - & - & up (18) & down (18) & - & up (18) \\
\hline 24 & $\begin{array}{l}\text { proline iminopeptidase, } \\
\text { putative [Ricinus communis] }\end{array}$ & gi|223538638 & 44547 & 6.0 & 5 & 94 & 100.0 & 71 & 100.0 & up (18) & up (18) & up $(16,18)$ & up $(16,18)$ \\
\hline
\end{tabular}


Table 1 Unique proteins expressed differentially in HY versus LY palms at 12-18 WAP, or exhibiting temporal expression differences in HY palms (Continued)

\begin{tabular}{|c|c|c|c|c|c|c|c|c|c|c|c|c|c|}
\hline & Stress related proteins & & & & & & & & & & & & \\
\hline 80 & $\begin{array}{l}17.6 \mathrm{kDa} \text { class I small heat shock } \\
\text { protein (HSP17.6C-Cl) (AA } \\
\text { 1-156) [Arabidopsis thaliana] }\end{array}$ & gi|15220832 & 17593.0 & 5.4 & 5 & 70 & 94.0 & 30 & - & - & - & up (16. 18) & up (18) \\
\hline 7 & OSJNBb0085F13.17 [Oryza sativa] & gi|38345312 & 80199.8 & 5.1 & 12 & 102 & 100.0 & 28 & - & down (16) & nt & - & $\mathrm{nt}$ \\
\hline 54 & $\begin{array}{l}\text { glutathione peroxidase } \\
\text { [Triticum monococcum] }\end{array}$ & gi|148529480 & 11668.8 & 5.7 & 3 & 73 & 97.0 & 50 & 97.9 & up (16) & down (16) & - & up (18) \\
\hline 41 & $\begin{array}{l}\text { glutathione S-transferase Phi } \\
\text { [Matricaria chamomilla] }\end{array}$ & gi|17385642 & 25264.9 & 6.0 & 5 & 96 & 100.0 & 69 & 100.0 & down (16) & - & up (16) & up $(16,18)$ \\
\hline 43 & $\begin{array}{l}\text { glutathione-S-transferase theta, } \\
\text { gst, putative [Ricinus communis] }\end{array}$ & gi|223528475 & 24482.6 & 5.8 & 1 & 82 & 99.6 & 77 & 100.0 & up (18) & nt & up $(16,18)$ & $\mathrm{nt}$ \\
\hline 78 & $\begin{array}{l}\text { abscisic stress ripening protein } \\
\text { [Musa acuminata] }\end{array}$ & gi|219963178 & 16735.8 & 5.6 & 3 & 76 & 98.5 & 51 & 97.8 & - & nt & down $(16,18)$ & $\mathrm{nt}$ \\
\hline \multirow[t]{2}{*}{53} & $\begin{array}{l}\text { temperature-induced lipocalin } \\
\text { [Elaeis guineensis] }\end{array}$ & gi|192911934 & 21614.8 & 5.7 & 5 & 93 & 100.0 & 51 & 98.8 & up (16) & - & up (16) & up (18) \\
\hline & Structure related proteins & & & & & & & & & & & & \\
\hline 22 & actin [Populus trichocarpa] & gi|224117708 & 40592.4 & 5.1 & 15 & 375 & 100.0 & 258 & 100.0 & down (16) & - & - & up (18) \\
\hline 23 & $\begin{array}{l}\text { caffeic acid O-methyltransferase } \\
\text { [Vanilla planifolia] }\end{array}$ & gi|45444737 & 40632.5 & 5.7 & 4 & 92 & 100.0 & 72 & 100.0 & down $(12,16)$ & down $(12,16)$ & down $(16,18)$ & - \\
\hline 73 & $\begin{array}{l}\text { fibrillin-like protein [Elaeis } \\
\text { guineensis] }\end{array}$ & gi|32250939 & 18991.0 & 5.0 & 7 & 109 & 100.0 & 37 & 46.0 & up (12) & $\mathrm{nt}$ & down (16) & $\mathrm{nt}$ \\
\hline \multirow[t]{2}{*}{68} & $\begin{array}{l}\text { Os12g0163700 (actine gamma 2) } \\
\text { [Oryza sativa] }\end{array}$ & gi|115487492 & 39837.0 & 5.3 & 10 & 137 & 100.0 & 62 & 99.9 & - & - & up $(16,18)$ & up (18) \\
\hline & Other Proteins & & & & & & & & & & & & \\
\hline 13 & $\begin{array}{l}\text { V-type proton ATPase catalytic } \\
\text { subunit A [Daucus carota] }\end{array}$ & gi|137460 & 68792 & 5.3 & 17 & 250 & 100.0 & 107 & 100.0 & down (16) & down (16) & down (16) & up (18) \\
\hline 9 & catalase 2 [Elaeis guineensis] & gi|192910916 & 56922.4 & 6.5 & 11 & 100 & 100.0 & 25 & - & up (18) & up (18) & - & up (18) \\
\hline 56 & $\begin{array}{l}\text { large subunit of ribulose-1, } \\
5 \text {-bisphosphate carboxylase/ } \\
\text { oxygenase [Chlorogonium } \\
\text { elongatum] }\end{array}$ & gi|74267421 & 41910.0 & 7.0 & 5 & 71 & 95.3 & 40 & 73.0 & up (18) & up (18) & up $(16,18)$ & up (18) \\
\hline 32 & $\begin{array}{l}\text { Ran GTPase binding protein } \\
\text { [Ricinus communis] }\end{array}$ & gi|223434074 & 119713.4 & 9.0 & 12 & 67 & 87.9 & - & - & up (12) & - & up $(16,18)$ & up (18) \\
\hline 72 & $\begin{array}{l}\text { ribosomal protein L10 } \\
\text { [Elaeis guineensis] }\end{array}$ & gi|192910684 & 34609.4 & 5.4 & 6 & 251 & 100.0 & 198 & 100.0 & down (12) & down (12) & up $(16,18)$ & up $(16,18)$ \\
\hline 49 & $\begin{array}{l}\text { ABC1 family protein } \\
\text { [Arabidopsis thaliana] }\end{array}$ & gi|79325958 & 73790.7 & 5.6 & 13 & 73 & 96.7 & - & - & down (18) & - & down (18) & up $(16,18)$ \\
\hline 48 & Lea1P [Daucus carota] & gi|10945667 & 16361.9 & 7.8 & 7 & 66 & 84.5 & - & - & up (16) & - & up (16) & up (18) \\
\hline 33 & $\begin{array}{l}\text { nascent polypeptide associated } \\
\text { complex alpha [Vitis vinifera] }\end{array}$ & gi|225470846 & 22013.8 & 4.3 & 5 & 305 & 100.0 & 262 & 100.0 & up (12) & down (12) & down $(16,18)$ & up $(16,18)$ \\
\hline
\end{tabular}


Table 1 Unique proteins expressed differentially in HY versus LY palms at 12-18 WAP, or exhibiting temporal expression differences in HY palms (Continued)

\begin{tabular}{|c|c|c|c|c|c|c|c|c|c|c|c|c|c|}
\hline 58 & Os02g0753300 [Oryza sativa] & gi|115448731 & 19972.8 & 6.2 & 2 & 87 & 99.9 & 71 & 100.0 & up (16) & nt & - & $\mathrm{nt}$ \\
\hline 66 & Os05g0482700 [Oryza sativa] & gi|115464537 & 60774.8 & 5.3 & 10 & 256 & 100.0 & 183 & 100.0 & - & nt & down (16) & $\mathrm{nt}$ \\
\hline 84 & $\begin{array}{l}\text { regulator of ribonuclease } \\
\text { activity } \mathrm{A} \text { [Zea mays] }\end{array}$ & gi|195638112 & 18105.2 & 5.8 & 5 & 80 & 99.4 & 34 & - & - & $\mathrm{nt}$ & up $(16,18)$ & $\mathrm{nt}$ \\
\hline 36 & $\begin{array}{l}\text { retroelement pol polyprotein- } \\
\text { like [Arabidopsis thaliana] }\end{array}$ & gi|9759493 & 126284.1 & 9.0 & 15 & 66 & 85.2 & - & - & down (12) & nt & up (16) & $\mathrm{nt}$ \\
\hline 59 & $\begin{array}{l}\text { conserved hypothetical protein } \\
\text { [Ricinus communis] }\end{array}$ & gi|223539131 & 16333.4 & 6.6 & 1 & 55 & - & 49 & 97.5 & up (16) & nt & up $(16,18)$ & $\mathrm{nt}$ \\
\hline 34 & $\begin{array}{l}\text { predicted protein [Ostreococcus } \\
\text { lucimarinus CCE9901] }\end{array}$ & gi|145345862 & 14575.0 & 4.6 & 3 & 66 & 85.2 & 46 & 92.4 & up (16) & nt & up (16) & $\mathrm{nt}$ \\
\hline 79 & $\begin{array}{l}\text { predicted protein } \\
\text { [Physcomitrella patens] }\end{array}$ & gi|168027637 & 23578.3 & 6.9 & 2 & 70 & 93.8 & 58 & 99.7 & - & $\mathrm{nt}$ & up (16) & $\mathrm{nt}$ \\
\hline 55 & $\begin{array}{l}\text { hypothetical protein isoform } \\
1 \text { [Vitis vinifera] }\end{array}$ & gi|225434277 & 22608.8 & 8.7 & 5 & 88 & 99.9 & 54 & 99.0 & up (12) & $\mathrm{nt}$ & down (18) & $\mathrm{nt}$ \\
\hline
\end{tabular}

Identification of proteins was carried out using MASCOT against the NCBI non-redundant database

bWestern dot blot immunoassay was conducted for validation. up $=$ up regulated, down $=$ down regulated, $-=$ no differential, $n t$ not tested 
biosynthesis is still relatively minimal (Fig. 4). Tranbarger et al. [17] also observed a higher abundance of biotin carboxylase transcripts during oil biosynthesis. Biotin carboxylase subunit is a component of acetyl-coenzyme A carboxylase [46]. Acetyl-CoA carboxylase catalyzes the conversion of acetyl-CoA to malonyl-CoA as the initial step of de novo fatty acid synthesis occurring in the plastid [46]. It has been demonstrated that over-expression of foxtail millet acetyl-CoA carboxylase gene in maize increases seed oil content by 25 to $65 \%$ [47]. Although, no differential abundance was observed between HY and LY palms in this study, the importance of biotin carboxylase to lipid production in oil palm mesocarp is clearly evident.

\section{Carbohydrate metabolism}

DIGE results identified three enzymes involved in glycolysis as being produced at a different levels between HY and LY palms; fructose-1,6-biphosphate aldolase (FBA), triosephosphate isomerase (TPI) and glyceraldehyde-3-phosphate dehydrogenase (GAPDH). Results of western analysis for FBA and TPI were concordant with DIGE data (Fig. 3). During the last stages of glycolysis, FBA fragments fructose-1,6biphosphate into glyceraldehyde-3-phosphate (GAP) and dihydroxyacetonephosphate (DHAP), while TPI acts as a housekeeping enzyme to catalyze the interconversion and maintain appropriate balance of GAP and DHAP concentrations. Subsequently, GAP is converted to 1,3-bisphosphoglycerate by GAPDH and then eventually leads to pyruvate. Meanwhile, glycerol-3-phosphate dehydrogenase converts DHAP to glycerol 3-phosphate, an important intermediate of the acylglycerol backbone. FBA was observed to be up-regulated at 16 and 18 WAP, concordant with lipid biosynthesis (Fig. 4), and more interestingly have higher abundance in HY palms at 16 WAP (Fig. 3). The up-regulation of FBA in HY palms is likely to contribute to increased flux through glycolysis into de novo fatty acid synthesis [10, 48]. Interestingly, DIGE analysis indicated that TPI and GAPDH were both down-regulated in HY palms at 16 WAP. These findings are consistent with observations in sunflower where TPI and GAPDH activities were found to be higher in the low-oil content sunflower lines [11]. However, they also reported that FBA exhibited higher activity in low-oil lines. Studies of yeast [49] and canola [14] also demonstrated that reduced TPI activity causes a shift in glycolytic flux towards glycerol leading to increased yield. It is likely that a concurrent reduction in GAPDH activity would further alter the flux balance at this important branch point in the glycolysis pathway. Detailed metabolite comparisons of HY and LY oil palms provide further evidence of this flux balance change where glycerol-3-phosphate levels were observed to be $43 \%$ higher in HY mesocarp at 16 WAP, while downstream of GAP, 3-phosphoglyceric acid levels were $26 \%$ lower [19].

Receiver operating characteristic (ROC) curves [50] were generated using TPI protein levels detected in HY and LY palms at 12 and 16 WAP (Figs. 5). The generalized area under the curve for both time points was calculated to be 0.80 and 0.85 , respectively, indicating the potential use of TPI as a yield biomarker.

\section{Amino acid metabolism}

Several enzymes involved in amino acid metabolism were found to have significantly higher levels during lipid biosynthesis (Fig. 4). Although, no significant

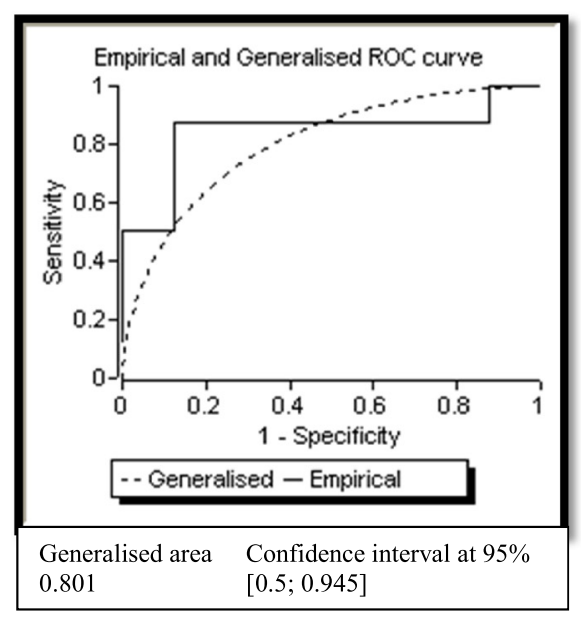

(A)

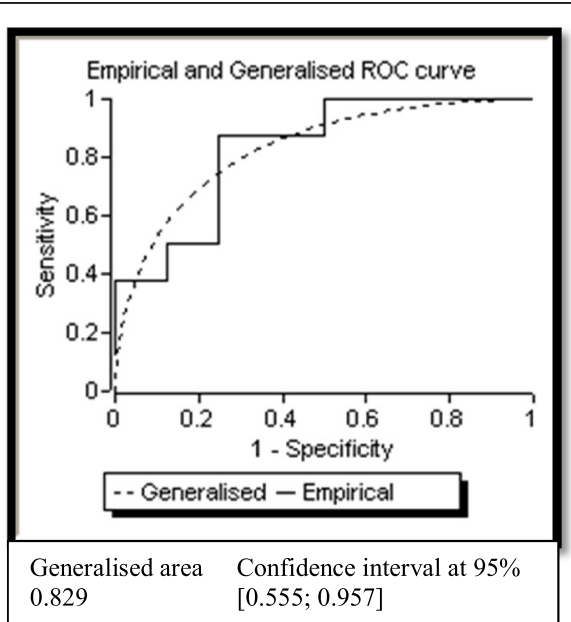

(B)

Fig. 5 Receiver operating characteristic (ROC) curves plotted for triosephosphate isomerase enzyme at 12 (a) and 16 (b) WAP. Area under the curve greater than 0.75 is indicative of a good diagnostic marker 
differences were observed in their levels between HY and LY palms. A separate study by Teh et al. [19] has shown there are significantly higher concentrations of amino acids in the mesocarp of HY oil palms at the onset of lipid biosynthesis. Tranbarger et al. [17] has also reported higher amino acid concentrations in oil palm compared to its non-oil-producing relative, date palm. Taken together, these results suggest that the regulation and metabolism of amino acids before and during lipid biosynthesis may play a crucial role in fruit maturation and oil yield.

\section{Structural protein}

Our DIGE and western immunoassay results indicated that the enzyme caffeic acid O-methyltransferase (COMT) was more abundance in LY palms compared to HY palms at 12 WAP [2.1x, $p<0.05]$ and 16 WAP [3.3x, $p<0.05$ ] (Table 1, Fig. 3 and Additional file 2). COMT is a key enzyme in the lignin biosynthetic pathway [51] and it is plausible that a reduction in lignin biosynthesis may be complimentary to higher lipid production in mesocarp tissue.

\section{Other proteins}

Abundance of several other proteins were found to be altered in the course of oil palm fruit development. One is the Vacuolar $\mathrm{H}+-$ ATPase (V-ATPase). It is important for secondary ion transport into the expanding vacuole and as a regulator of membrane trafficking in higher plants [52]. In pear trees, V-ATPase activity is reported to be down-regulated during the flowering stage and markedly increases during early developmental stages and fruit growth [53, 54]. In oil palm mesocarp, the level of V-ATPase was observed to be higher in LY palms [1.9x, $\mathrm{p}<0.05$ ] (Additional file 2) at 16 WAP compared to HY palms using DIGE (Table 1) and western analysis (Fig. 3). The direct role of V-ATPase in contributing to the onset of oil biosynthesis in oil palm at 16 WAP is unknown. Our results here, however, suggested that this enzyme may associate with oil biosynthesis in oil palm.

Other proteins that showed differential abundance in HY palms have been reported to be associated with oil yield. Our DIGE analysis led to the identification of seven stress related proteins such as $17.6 \mathrm{kDa}$ class I small heat shock protein [55], glutathione S-transferase [56] and glutathione peroxidase [57]. Studies of maize and sunflower have also found higher level of stress response proteins in high-yielding lines [10, 12]. We also observed that catalase was higher in abundance in the mesocarp of HY palms at 18 WAP (Additional file 2). Catalase plays a role in the regulation of hydrogen peroxide and reactive oxygen species, and has been reported to be important during sunflower and maize seed development and oil biosynthesis $[13,58,59]$ as well as in peach mesocarp development [60]. Large subunit ribulose-1,5-bisphosphate caboxylase/oxygenase (Rubisco) is another protein found to have higher levels in HY palms at 18 WAP (Additional file 2). The abundance of Rubisco was also clearly correlated with lipid biosynthesis, increasing steadily from 12 to 18 WAP (Fig. 4). Rubisco is the most abundant protein found in plants and is known to play a crucial role in photosynthetic carbon assimilation. Studies on developing embryos of Brassica napus indicated that Rubisco increases the efficiency of carbon use for triacylglycerol production without the Calvin cycle $[14,61]$ and its expression has been linked with yield in maize $[62,63]$.

Several transcriptomics studies report the importance of transcription factor WRINKLED1 in oil biosynthesis in Arabidopsis, maize and oil palm [17, 18, 21, 64-67]. In oil palm mesocarp, Tranbarger et al. [17], Dussert et al. [21] and Wong et al. [18] all noted positive correlation between oil deposition during fruit maturity and WRINKLED1 expression; mRNA of WRINKLED1 increased from 12 WAP to 16 WAP and subsequently decreased from 18 WAP onwards. Conversely, the temporal changes of WRINKLED1 protein abundance during fruit development was not observed in the present DIGE study. Incidentally, alteration in protein level of any transcription factors was neither observed in DIGE analysis of maize differing in oil trait by Hadjuch et al. [10], nor in 2D gel comparative analyses of Brassica campestri oilseed development [68] or of Olea europaea olive fruit development [15]. Transcription factors are generally expressed in very low amount in a cell, both as RNA and protein, because only small quantity are required for activation of cognate genes. Hence, it is not impossible that the mesocarp WRINKLED1 protein is being produced in very low concentration that it is beyond the detection limit of the DIGE technique deployed here. In addition, it is not unknown that proteins of low abundance are being masked by proteins of higher abundance in this gel-based proteomics analysis $[69,70]$, thus making their detection challenging.

\section{Conclusions}

In summary, 2D-DIGE techniques identified forty-one protein candidates as being differentially accumulated in two genetically related populations of oil palm displaying a 2-fold difference in yield. While only two of the proteins are known to be involved in oil metabolism, many are involved in other important pathways such as glycolysis, energy metabolism, amino acid metabolism and structural proteins. These results confirm that oil yield is a complex trait involving the regulation of genes in multiple biological pathways. In particular, two important glycolytic enzymes FBA and TPI exhibit differential levels in high-yielding palms, and suggest altered flux 
balance between DHAP and GAP may lead to increased yield. Results also showed that the regulation of amino acid metabolism appears to be closely linked to lipid biosynthesis. Better understanding of the biochemical differences leading to increased oil yield in Elaeis guineensis will aid the identification of key biosynthetic control points in addition to enabling the identification of markers for use in breeding programmes.

\section{Methods \\ Plant material}

Sixteen sibling or half-sibling palms derived from crosses of Serdang Avenue dura and AVROS pisifera and grown in the same field at Carey Island Estate, Malaysia were selected for this study. Oil yield and fruit bunch analysis data were collected for individual plants over a 7 year period. Eight palms were identified as high-yielding with yields of $10-12 \mathrm{t} / \mathrm{Ha} / \mathrm{y}$, and 8 were relatively low-yielding with $4-7 \mathrm{t} / \mathrm{Ha} / \mathrm{y}$ [19]. Fruit bunches were harvested at 12, 16 , and 18 weeks after pollination to represent key lipid biosynthesis phases [3, 17, 27-29]. Mesocarp tissues were collected, immediately frozen in liquid nitrogen then stored at $-80{ }^{\circ} \mathrm{C}$ prior to use. The permission for sample collection was obtained from the owner of the estate, Sime Darby Plantation Malaysia. No specific permissions were required for the location and the field studies, because the project did not involve any protected or endangered plant species.

\section{Mesocarp protein extractions for 2D gel electrophoresis} In order to find a suitable protein extraction method for 2D gel experiments using mesocarp protein, 3 methods were compared. They were (i) the sucrose method [25], (ii) a modified sucrose method and (iii) the phenol/ammonium acetate method [26].

\section{The sucrose method}

He et al [25] $10 \mathrm{~mL}$ sucrose extraction buffer (5\% sucrose, $4 \%$ SDS and $5 \% \beta$-mercaptoethanol) and $0.1 \mathrm{~g}$ PVPP were added to $1 \mathrm{~g}$ pulverized tissue and the mixture was swirled gently for $10 \mathrm{~min}$ at room temperature. After centrifugation at $10,000 \mathrm{~g}$ for $5 \mathrm{~min}$, the supernatant was heated at $100{ }^{\circ} \mathrm{C}$ for $3 \mathrm{~min}$ and cooled to room temperature. Eight volumes of cold acetone were then added to the cooled supernatant. The mixture was incubated at $-20{ }^{\circ} \mathrm{C}$ for at least $1 \mathrm{~h}$, prior to centrifugation at $10,000 \mathrm{~g}$ for $10 \mathrm{~min}$. The resulting pellet was resuspended in $5 \mathrm{~mL}$ sucrose extraction buffer before being centrifuged at 10,000 g for $10 \mathrm{~min}$. The protein pellet was washed twice in $80 \%$ cold acetone and finally precipitated in 4 volumes of cold acetone before air drying.

\section{The modified sucrose method}

In the sucrose modified method, the steps found in the sucrose method [25] were followed from the start until the re-suspension of protein pellet in $5 \mathrm{~mL}$ sucrose extraction buffer. From here, the insoluble material was removed by centrifugation at $10,000 \mathrm{~g}$ for $5 \mathrm{~min}$ at room temperature. Sequentially, 4 volumes of cold acetone were added to the clear supernatant prior to incubation for $1 \mathrm{~h}$ at $-20{ }^{\circ} \mathrm{C}$. Following centrifuging for $10 \mathrm{~min}$, the new pellet was washed twice in $80 \%$ cold acetone and once in cold acetone before air drying. All centrifugal procedures in this method were carried out at $4{ }^{\circ} \mathrm{C}$, unless stated otherwise.

\section{The phenol/ammonium acetate method}

Two $\mathrm{mL}$ cold $10 \%$ TCA/acetone was added to $300 \mathrm{mg}$ of pulverized mesocarp tissue, and the mixture was thoroughly mixed before centrifuging at 16,000 $\mathrm{g}$ for $3 \mathrm{~min}$ at $4{ }^{\circ} \mathrm{C}$. The supernatant was discarded and $2 \mathrm{~mL}$ ammonium acetate $(0.1 \mathrm{M})$ in $80 \%$ methanol was added to the pellet and the mix was vortexed prior to being centrifuged at $16,000 \mathrm{~g}$ for $3 \mathrm{~min}$ at $4{ }^{\circ} \mathrm{C}$. The supernatant was discarded and the pellet was washed in $80 \%$ acetone by vortexing. The mixture was centrifuged at $16,000 \mathrm{~g}$ for $3 \mathrm{~min}$ at $4{ }^{\circ} \mathrm{C}$ and the supernatant removed. The resulting pellet was air-dried at room temperature or incubated at least $50{ }^{\circ} \mathrm{C}$ to remove residual methanol. Sequentially, the protein in the dried pellet was extracted by vortexing vigorously in $2 \mathrm{~mL}$ of $1: 1$ phenol $\mathrm{pH} 8.0$ / SDS buffer [SDS buffer: $0.1 \mathrm{M}$ Tris- $\mathrm{HCl}$ (pH 8.0), $30 \%$ sucrose, $2 \%$ SDS, $5 \% \beta$-mercaptoethanol] for $5 \mathrm{~min}$. The mixture was centrifuged at $16,000 \mathrm{~g}$ for $3 \mathrm{~min}$ at $4^{\circ}$ $\mathrm{C}$ and the phenol phase (top phase) was collected. The protein in the phenol phase was precipitated by adding $2 \mathrm{~mL}$ methanol containing $0.1 \mathrm{M}$ ammonium acetate and stored overnight at $-20{ }^{\circ} \mathrm{C}$. The protein was pelleted by centrifuging at $16,000 \mathrm{~g}$ for $5 \mathrm{~min}$ at $4{ }^{\circ} \mathrm{C}$ before being washed in methanol by vortexing. After centrifuged at $16,000 \mathrm{~g}$ for $3 \mathrm{~min}$ at $4{ }^{\circ} \mathrm{C}$, the pellet was washed in $80 \%$ acetone. A final centrifugation at $16,000 \times \mathrm{g}$ for 3 min at $4{ }^{\circ} \mathrm{C}$ was carried out and the supernatant discarded. The final pellet was allowed to air dry.

The protein pellet obtained from each method aforementioned was then re-suspended in lysis buffer containing $30 \mathrm{mM}$ Tris- $\mathrm{HCl}(\mathrm{pH}$ 8.8), $7 \mathrm{M}$ urea, $2 \mathrm{M}$ thiourea and $4 \%$ CHAPS. The mixture was sonicated for $30 \mathrm{~min}$ at room temperature and centrifuged at $14,000 \mathrm{rpm}$ for $30 \mathrm{~min}$ at room temperature and the resulting supernatant was collected. Protein concentration of the supernatant was determined using the Bradford assay method [71].

The extracted proteins were used for the production of 2D gels. Briefly, for first dimension separation, $3 \mu \mathrm{g}$ protein extract was passive-loaded into a $7 \mathrm{~cm} \mathrm{pH3-10}$ 
NL IPG strip (GE Healthcare), prior to being isoelectric focused for $9 \mathrm{kvh}$ using the Ettan IPGphor III system (GE Healthcare). For the second dimension separation, the proteins from the strip were electrophoresed through a $12 \%$ SDS polyacrylamide gel. The 2D gel was silverstained [72] and it image was digitalized by Image Master Image Scanner III (GE Healthcare). Subsequently, spot analysis was performed on the digitalized image utilizing Image Master Platinum 7 software (GE Healthcare).

\section{Two dimensional differential gel electrophoresis (DIGE)}

Mesocarp samples of $3 \mathrm{HY}$ and $3 \mathrm{LY}$ oil palms (biological replicates) at 12, 16 and 18 WAP were selected for initial DIGE screening.

\section{Setup of 2D-DIGE analytical gels}

A total of 9 DIGE gels were produced for comparative analysis with sample pairing of HY and LY palm samples at each time point. An internal standard containing a pool of all 18 samples was included on the DIGE gels to aid peptide spot comparison between gels.

\section{CyDye labeling}

For each sample, $30 \mu \mathrm{g}$ of protein was mixed with $1.0 \mu \mathrm{L}$ of diluted CyDye, and kept on ice in the dark for 30 min. Samples from each pair of HY and LY were labeled with $\mathrm{Cy} 3$ and $\mathrm{Cy} 5$, respectively, while the internal standard was labeled with Cy2. The labeling reaction was quenched with $1.0 \mu \mathrm{L}$ of $10 \mathrm{mM}$ lysine followed by further incubation for $15 \mathrm{~min}$. The HY, LY and internal standard samples were then mixed together. Two times 2-D sample buffer (8 M urea, 4\% CHAPS, $20 \mathrm{mg} / \mathrm{mL}$ DTT, 2 \% Pharmalyte and trace amount of bromophenol blue), Destreak solution $(100 \mu \mathrm{L})$ and rehydration buffer (7 M urea, $2 \mathrm{M}$ thiourea, $4 \%$ CHAPS, $20 \mathrm{mg} / \mathrm{mL}$ DTT, $1 \%$ Pharmalyte and trace amount of bromophenol blue) were added to the labeling mix to make a total volume of $250 \mu \mathrm{L}$. The resulting solution was mixed thoroughly and centrifuged prior to loading onto immobilized $\mathrm{pH}$ 4-7 gradient gel (IPG) strips.

\section{IEF (isoelectric focusing) and SDS-PAGE (polyacrylamide gel electrophoresis)}

IEF was run following the protocol provided by Amersham BioSciences [73]. Once IEF was completed, the IPG strips were incubated in freshly prepared equilibration buffer-1 (50 mM Tris- $\mathrm{HCl}, \mathrm{pH} 8.8$, containing $6 \mathrm{M}$ urea, $30 \%$ glycerol, $2 \%$ SDS, trace amount of bromophenol blue and $10 \mathrm{mg} / \mathrm{mL} \mathrm{DTT}$ ) for $15 \mathrm{~min}$ with gentle shaking. The strips were then rinsed in freshly prepared equilibration buffer-2 $(50 \mathrm{mM}$ Tris- $\mathrm{HCl}$, pH 8.8, containing $6 \mathrm{M}$ urea, $30 \%$ glycerol, $2 \%$ SDS, trace amount of bromophenol blue and $45 \mathrm{mg} / \mathrm{mL}$ DTT) for $10 \mathrm{~min}$ with gentle shaking. Lastly, the IPG strips were rinsed in SDS-gel running buffer before transferring into $12 \%$ SDS-gels and run at $15{ }^{\circ} \mathrm{C}$.

\section{Image scan and data analysis}

Gel images were scanned immediately following SDSPAGE using Typhoon TRIO (Amersham BioSciences). The scanned images were then analyzed using Image-Quant software (Version 6.0, Amersham BioSciences), followed by Biological Variation Analysis (BVA) using DeCyder ${ }^{\mathrm{Ts}}$ 2D software Version 6.5 (Amersham BioSciences).

\section{Protein Identification by MALDI TOF/TOF mass spectrometer}

Three preparative gels were prepared from running nonlabeled proteins (ca $200 \mu \mathrm{g}$ each) and spots were picked up from the gels by the aid of automated Ettan Spot Picker (Amersham BioSciences). The gel spots were washed, dried, and rehydrated in trypsin digestion buffer containing modified porcine trypsin protease (Trypsin Gold, Promega) at $37^{\circ} \mathrm{C}$. The trypsinized peptides were desalted by $\mathrm{C} 18$ Zip-tip (Millipore), eluted in matrix solution $(5 \mathrm{mg} / \mathrm{ml}$ $\alpha$-cyano-4-hydroxycinnamic acid in $50 \%$ acetonitrile, $0.1 \%$ trifluoroacetic acid, $25 \mathrm{mM}$ ammonium bicarbonate) and spotted into wells of a MALDI plate. MALDI-TOF and TOF/TOF tandem MS were performed on an ABI 4700 mass spectrometer (Applied Biosystems, Framingham, MA). The mass spectra of MALDI-TOF were acquired in reflectron positive ion mode (ca. 4000 laser shots per spectrum). Tandem MS/MS fragmentation spectra of TOF/TOF were acquired (ca. 4000 laser shots per fragmentation spectrum) from 10 most abundant ions present in each sample. Protein identities were determined by searching against the database of National Center for Biotechnology Information non-redundant (NCBInr) with the combined MS and MS/MS spectra using GPS Explorer software equipped with the MASCOT search engine (Matrix Science). Searches were performed with carbamido methylation of cysteine and oxidation of methionine residues, and with allowance of one missed cleavage of trypsin. Hits with either protein score C.I.\% greater than 80 or Ion C.I.\% greater than 95 were considered significant. Precursor tolerance was set to $150 \mathrm{ppm}$ and MS/MS tolerance was set to 0.4 Da.

\section{Validation of DIGE results using western analysis}

Dot blot immunoassays were conducted on all 16 of the HY and LY samples collected at each of 12, 16 and 18 WAP (Additional file 4, Additional file 5, Additional file 6, Additional file 7). The specificity of antibodies used in the immunoassays was tested by $1 \mathrm{D}$ or 2D SDS-PAGE blots (Additional file 4; 1D and 2D SDS-PAGE methods are described in Additional file 5). Mesocarp proteins for dot blot immunoassays were extracted using the TCA-acetone 
method described by Carpentier et al. [74]. The resulting protein pellet was re-dissolved and stored in urea buffer (9 M urea, 4 \% CHAPS, 1 \% DTT, $1 \%$ ampholytes pH3-10, $35 \mathrm{mM}$ Tris base). The concentration of the protein extract was determined using the Bradford method [71]. Using a 386-pin replicator, protein samples were spotted onto nitrocellulose membranes. The membranes were allowed to dry overnight before incubation with a primary antibody. An alkaline phosphatase labeled secondary antibody was used for colorimetric detection with NBT/BCIP. Images of the membranes were scanned using Adobe Photoshop C84 Extended \& Olympus Micro software to automatically capture and transform spot intensities into Microsoft Excel ${ }^{\circ}$ data format. Comparisons between two populations were performed by using the Student $t$-test (Microsoft Excel ${ }^{\circ}$ 2007). The receiver operating characteristic (ROC) curve was plotted using mROC (Version 1.0) by CIS Bio International.

\section{Additional files}

\section{Additional file 1: Two dimensional DIGE gels produced for spot analysis using $13 \mathrm{~cm}$ IEF strips of $\mathrm{pH}$ 4-7 with 20-kVh focusing. Gel images of DIGE experiments labeled with Cy 3 and Cy 5 and their overlays.} (PDF $2904 \mathrm{~kb}$ )

Additional file 2: Data of Biological Variation Analysis (BVA) on DIGE gels. Results of Biological Variation Analysis (BVA) on DIGE gels are given in a table. (PDF $95 \mathrm{~kb}$ )

Additional file 3: Protein-peptide summary of MASCOT protein identification. Protein-peptide summary of MASCOT protein identification. (XLSX $396 \mathrm{~kb}$ )

Additional file 4: Validation of DIGE results by western analysis. Results of western immunoblots carried out in this study. (PDF 193 kb)

Additional file 5: Protocols for electrophoresis and immunoblotting for western analysis, and antibodies used in this study. Methods for 1D and 2D-SDS PAGE for immunoblots analysis and the list of antibodies used in this study. (PDF $77 \mathrm{~kb}$ )

Additional file 6: Analysis of dot intensity of immunoblots for comparison of protein levels in mesocarp of high yielding and low yielding oil palms at 12,16 and 18 week after pollination. Analysis of dot intensity of immunoblots for comparison of protein levels in mesocarp of high yielding and low yielding oil palms at 12, 16 and 18 week after pollination. (PDF $120 \mathrm{~kb}$ )

Additional File 7: Dot intensity analysis of immunoblots for time points comparison (12 vs 16 week after pollination and 12 vs 18 week after pollination) of mesocarp protein levels in high yielding oil palms. Dot intensity analysis of immunoblots for time points comparison (12 vs 16 week after pollination and 12 vs 18 week after pollination) of mesocarp protein levels in high yielding oil palms (PDF $74 \mathrm{~kb})$

\section{Abbreviations}

HY: High-yielding; LY: Low-yielding; WAP: Weeks after pollination.

\section{Competing interests}

The authors have declared no competing interests in this study.

\section{Authors' contributions}

TEKO, WCY, LDJD, BZN, FTC and HK participated in the conception and designing the study. TEKO, LDJD, WCY and BZN performed the 2D gel and DIGE experiments. WCY, BZN, FCL and AMO carried out the western immunoassays. TEKO, WCY, FCL, FTC and DRA help to draft the manuscript. All authors read and approved the final manuscript.

\section{Acknowledgments}

The authors acknowledge Sime Darby Plantation, Malaysia for funding the project. The authors offer thanks to their colleagues at Sime Darby R \& D Centres, especially to Claude Bakoume and Mohaimi Mohamed for ascertainment and sample attainment of the low/high yielding palms. Applied Biomics, Inc. of San Francisco, California is recognized for their assistance in DIGE work.

\section{Author details}

${ }^{1}$ Sime Darby Technology Centre Sdn. Bhd., UPM-MTDC Technology Centre III, Lebuh Silikon, Universiti Putra Malaysia, 1st Floor, Block B, 43400 Serdang, Selangor, Malaysia. ${ }^{2}$ Agro-Biotechnology Institute Malaysia, National Institutes of Biotechnology Malaysia, c/o MARDI Headquarters, 43400 Serdang, Selangor, Malaysia. ${ }^{3}$ Department of Biological Sciences, Faculty of Science, National University of Singapore, Kent Ridge Road, Singapore 117543, Singapore.

Received: 3 August 2015 Accepted: 22 November 2015

Published online: 26 November 2015

\section{References}

1. Murphy DJ. Oil palm: future prospects for yield and quality improvements. Lipid Technol. 2009;21:257-60.

2. Salas JJ, Sánchez J, Ramli US, Manaf AM, Williams M, Harwood JL. Biochemistry of lipid metabolism in olive and other oil fruits. Prog Lipid Res. 2000;39:151-80.

3. Sundram K, Sambanthamurthi R, Tan YA. Palm fruit chemistry and nutrition. Asia Pac J Clin Nutr. 2003;12:355-62.

4. Wang L, Wang X, Jin X, Jia R, Huang $Q$, Tan Y, et al. Comparative proteomics of Bt-transgenic and non-transgenic cotton leaves. Proteome Sci. 2015;13:1-15.

5. Ndimba B, Ngara R. Sorghum and sugarcane proteomics. In: Paterson AH, editor. Genomics of the Saccharinae, vol. 11. New York: Springer; 2013. p. 141-68. Plant Genetics and Genomics: Crops and Models].

6. Zhang XL, Qi MF, Xu T, Lu XJ, Li TL. Proteomics profiling of ethyleneinduced tomato flower pedicel abscission. J Proteomics. 2015;121:67-87.

7. Li X, Xu W, Chowdhury M, Jin F. Comparative proteomic analysis of labellum and inner lateral petals in Cymbidium Ensifolium flowers. Int J Mol Sci. 2014;15:19877.

8. Jiang C, Cheng Z, Zhang C, Yu T, Zhong Q, Shen JQ, et al. Proteomic analysis of seed storage proteins in wild rice species of the Oryza genus. Proteome Sci. 2014;12:1-12.

9. Budak H, Akpinar BA, Unver T, Turktas M. Proteome changes in wild and modern wheat leaves upon drought stress by two-dimensional electrophoresis and nanoLC-ESI-MS/MS. Plant Mol Biol. 2013;83:89-103.

10. Hajduch M, Casteel JE, Tang S, Hearne LB, Knapp S, Thelen JJ. Proteomic analysis of near-isogenic sunflower varieties differing in seed oil traits. J Proteome Res. 2007;6:3232-41.

11. Troncoso-Ponce MA, Garcés R, Martínez-Force E. Glycolytic enzymatic activities in developing seeds involved in the differences between standard and low oil content sunflowers (Helianthus annuus L.). Plant Physiol Biochem. 2010;48:961-5.

12. Liu Z, Yang X, Fu Y, Zhang Y, Yan J, Song T, et al. Proteomic analysis of early germs with high-oil and normal inbred lines in maize. Mol Biol Rep. 2009;36:813-21

13. Tsaftaris AS, Scandalios JG. Comparison of the glyoxysomes and the glyoxysomal enzymes in maize lines with high or low oil content. Plant Physiol. 1983;71:447-50.

14. Hajduch M, Casteel JE, Hurrelmeyer KE, Song Z, Agrawal GK, Thelen JJ. Proteomic analysis of seed filling in Brassica napus. Developmental characterization of metabolic isozymes using high-resolution twodimensional gel electrophoresis. Plant Physiol. 2006;141:32-46.

15. Bianco L, Alagna F, Baldoni L, Finnie C, Svensson B, Perrotta G. Proteome regulation during Olea europaea fruit development. PLoS One. 2013;8:e53563.

16. Bourgis F, Kilaru A, Cao X, Ngando-Ebongue G-F, Drira N, Ohlrogge JB, et al. Comparative transcriptome and metabolite analysis of oil palm and date palm mesocarp that differ dramatically in carbon partitioning. Proc Natl Acad Sci. 2011;108:12527-32.

17. Tranbarger TJ, Dussert $\mathrm{S}$, Joet $T$, Argout $X$, Summo M, Champion A, et al. Regulatory mechanisms underlying oil palm fruit mesocarp maturation, 
ripening, and functional specialization in lipid and carotenoid metabolism. Plant Physiol. 2011;156:564-84.

18. Wong $Y$, Kwong Q, Lee $H$, Ong C, Mayes S, Chew F, et al. Expression comparison of Oil biosynthesis genes in Oil palm mesocarp tissue using custom array. Microarrays. 2014;3:263.

19. Teh HF, Neoh BK, Hong PL, Low YS, Ng LM, Ithnin N, et al. Differential metabolite during fruit development in high-yielding oil palm mesocarp. PLoS One. 2013;8:e61344.

20. Neoh BK, Teh HF, Ng TL, Tiong SH, Thang YM, Ersad MA, et al. Profiling of metabolites in oil palm mesocarp at different stages of oil biosynthesis. J Agric Food Chem. 2013;61:1920-7.

21. Dussert S, Guerin C, Andersson M, Joët T, Tranbarger TJ, Pizot M, et al. Comparative transcriptome analysis of three Oil palm fruit and seed tissues that differ in oil content and fatty acid composition. Plant Physiol. 2013;162: 1337-58.

22. Mackintosh JA, Choi H-Y, Bae S-H, Veal DA, Bell PJ, Ferrari BC, et al. A fluorescent natural product for ultra sensitive detection of proteins in onedimensional and two-dimensional gel electrophoresis. Proteomics. 2003;3: 2273-88.

23. Chevalier F. Highlights on the capacities of "Gel-based" proteomics. Proteome Sci. 2010:8:1-10.

24. Teshima R, Nakamura R, Satoh R, Nakamura R. 2D-DIGE analysis of rice proteins from different cultivars. Regul Toxicol Pharmacol. 2010;58:S30-5.

25. He C-y, J-g Z, A-g D, J-y Y, D-s Z. Comparison of methods for protein extraction from pine needles. Forestry Stud China. 2005;7:20-3.

26. Wang W, Vignani R, Scali M, Cresti M. A universal and rapid protocol for protein extraction from recalcitrant plant tissues for proteomic analysis. Electrophoresis. 2006;27:2782-6.

27. Othman A, Lazarus C, Fraser T, Stobart K. Cloning of a palmitoyl-acyl carrier protein thioesterase from oil palm. Biochem Soc Trans. 2000;28:619-22.

28. Asemota O, Shah FH. Detection of mesocarp oleoyl-thioesterase gene of the South American oil palm Elaeis oleifera by reverse transcriptase polymerase chain reaction. Afr J Biotechnol. 2004:3:595-8.

29. Shaarani SM, Cardenas-Blanco A, Amin MHG, Soon NG, Hall LD. Monitoring development and ripeness of oil palm fruit (Elaeis guineensis) by MRI and bulk NMR. Int J Agric Biol. 2010;12:101-5.

30. Kanehisa M, Goto S. KEGG: kyoto encyclopedia of genes and genomes. Nucleic Acids Res. 2000;28:27-30.

31. Dudley JW, Lambert RJ: 100 Generations of Selection for Oil and Protein in Corn. In Plant Breeding Reviews. Volume 24. Edited by Janick J. Hoboken, New Jersey: John Wiley \& Sons, Inc.; 2010: 79-110.

32. Ramli US, Baker DS, Quant PA, Harwood JL. Use of control analysis to study the regulation of plant lipid biosynthesis. Biochem Soc Trans. 2002;30:1043-6.

33. Lamesch P, Berardini TZ, Li D, Swarbreck D, Wilks C, Sasidharan R, et al.: The Arabidopsis Information Resource (TAIR): improved gene annotation and new tools. Nucleic Acids Research 2012;40:D1202-12102, 40:D1202-1210.

34. The Arabidopsis Information Resource (TAIR) [https://www.arabidopsis.org/ servlets/TairObject?id=137515\&type=locus]

35. The Arabidopsis Information Resource (TAIR) [https://www.arabidopsis.org/ servlets/TairObject?id=137248\&type=locus]

36. The Arabidopsis Information Resource (TAIR) [https://www.arabidopsis.org/ servlets/TairObject?id=38410\&type=locus]

37. The Arabidopsis Information Resource (TAIR) [https://www.arabidopsis.org/ servlets/TairObject?id=27844\&type=locus]

38. The Arabidopsis Information Resource (TAIR) [https://www.arabidopsis.org/ servlets/TairObject?id=37115\&type=locus]

39. Mañas-Fernández A, Li-Beisson Y, Alonso D, García-Maroto F. Cloning and molecular characterization of a glycerol-3-phosphate O-acyltransferase (GPAT) gene from Echium (Boraginaceae) involved in the biosynthesis of cutin polyesters. Planta. 2010;232:987-97.

40. Chen S-L, Huang J-Q, Lei Y, Ren X-P, Wen Q-G, Chen Y-N, et al. Cloning and expression analysis of lysophosphatidic acid acyltransferase (LPAT) encoding gene in peanut. Acta Agron Sin. 2012;38:245-55.

41. Chen C-X, Sun Z, Cao H-S, Fang F-L, Ouyang L-L, Zhou Z-G. Identification and characterization of three genes encoding acyl-CoA: diacylglycerol acyltransferase (DGAT) from the microalga Myrmecia incisa Reisigl. Algal Res. 2015;12:280-8

42. Heller M. Phospholipase D. Adv Lipid Res. 1978;16:267-326.

43. Wang X. Multiple forms of phospholipase D in plants: the gene family, catalytic and regulatory properties, and cellular functions. Prog Lipid Res. 2000;39:109-49.
44. Qin C, Wang X. The Arabidopsis phospholipase D family. Characterization of a calcium-independent and phosphatidylcholine-selective PLD 11 with distinct regulatory domains. Plant Physiol. 2002;128:1057-68.

45. Yu Y. Investigation of potential roles of phospholipase D in Arabidopsis thaliana seed oil accumulation. Dept Botany: University of British Columbia; 2009.

46. Shorrosh BS, Roesler KR, Shintani D, van de Loo FJ, Ohlrogge JB. Structural analysis, plastid localization, and expression of the biotin carboxylase subunit of acetyl-coenzyme A carboxylase from tobacco. Plant Physiol. 1995;108:805-12.

47. Dong Z, Zhao H, He J, Huai J, Lin H, Zheng J, et al. Overexpression of a foxtail millet Acetyl-CoA carboxylase gene in maize increases sethoxydim resistance and oil content. Afr J Biotechnol. 2011;10:3986-95.

48. Hajduch M, Matusova R, Houston NL, Thelen JJ. Comparative proteomics of seed maturation in oilseeds reveals differences in intermediary metabolism Proteomics. 2011:11:1619-29.

49. Capitanio D, Merico A, Ranzi BM, Compagno C. Effects of the loss of triose phosphate isomerase activity on carbon metabolism in Kluyveromyces lactis. Res Microbiol. 2002;153:593-8.

50. Swets J. Measuring the accuracy of diagnostic systems. Science. 1988;240:1285-93.

51. Sewalt V, Ni W, Blount JW, Jung HG, Masoud SA, Howles PA, et al. Reduced lignin content and altered lignin composition in transgenic tobacco downregulated in expression of L-phenylalanine ammonia-lyase or cinnamate 4-hydroxylase. Plant Physiol. 1997;115:41-50.

52. Schumacher K, Krebs M. The V-ATPase: small cargo, large effects. Curr Opin Plant Biol. 2010;13:724-30.

53. Shiratake K, Kanayama Y, Maeshima M, Yamaki S. Changes in $\mathrm{H}(+)$-pumps and a tonoplast intrinsic protein of vacuolar membranes during the development of pear fruit. Plant Cell Physiol. 1997;38:1039-45.

54. Shiratake K, Martinoia E. Transporters in fruit vacuoles. Plant Biotech. 2007;24:127-33.

55. Efeoglu B. Heat shock proteins and heat shock response in plants. Gazi Univ J Sci. 2009;22:67-75.

56. Jain M, Ghanashyam C, Bhattacharjee A. Comprehensive expression analysis suggests overlapping and specific roles of rice glutathione S-transferase genes during development and stress responses. BMC Genomics. 2010;11:73.

57. Rodriguez Milla MA, Maurer A, Huete AR, Gustafson JP. Glutathione peroxidase genes in Arabidopsis are ubiquitous and regulated by abiotic stresses through diverse signaling pathways. Plant J. 2003;36:602-15.

58. Kibinza S, Bazin J, Bailly C, Farrant JM, Corbineau F, El-Maarouf-Bouteau H. Catalase is a key enzyme in seed recovery from ageing during priming. Plant Sci. 2011:181:309-15.

59. Polidoros AN, Scandalios JG. Response of the maize catalases to light. Free Radic Biol Med. 1997;23:497-504.

60. Nilo R, Saffie C, Lilley K, Baeza-Yates R, Cambiazo V, Campos-Vargas R, et al. Proteomic analysis of peach fruit mesocarp softening and chilling injury using difference gel electrophoresis (DIGE). BMC Genomics. 2010;11:43.

61. Schwender J, Goffman F, Ohlrogge JB, Shachar-Hill Y. Rubisco without the Calvin cycle improves the carbon efficiency of developing green seeds. Nature. 2004;432:779-82.

62. Loza-Tavera H, Serrano B. J.D. M, Ortega-Delgado ML, Sanchez-deJimenez $\mathrm{E}$ : $\mathrm{CO}_{2}$-fixation enzymes in maize (Zea mays) and grain yield. Can J Bot. 1987;65:607-11.

63. Loza-Tavera H, Martinez-Barajas E, Sanchez-de-Jimenez E. Regulation of ribulose-1,5-bisphosphate carboxylase expression in second leaves of maize seedlings from low and high yield populations. Plant Physiol. 1990;93:541-8.

64. Baud S, Mendoza MS, To A, Harscoët E, Lepiniec L, Dubreucq B. WRINKLED1 specifies the regulatory action of LEAFY COTYLEDON2 towards fatty acid metabolism during seed maturation in Arabidopsis. Plant J. 2007:50:825-38.

65. Cernac A, Benning C. WRINKLED1 encodes an AP2/EREB domain protein involved in the control of storage compound biosynthesis in Arabidopsis. Plant J. 2004;40:575-85.

66. Pouvreau B, Baud S, Vernoud V, Morin V, Py C, Gendrot G, et al. Duplicate maize Wrinkled1 transcription factors activate target genes involved in seed Oil biosynthesis. Plant Physiol. 2011;156:674-86.

67. Shen B, Allen WB, Zheng P, Li C, Glassman K, Ranch J, et al. Expression of ZmLEC1 and ZmWRI1 increases seed Oil production in maize. Plant Physiol. 2010;153:980-7.

68. Li W, Gao Y, Xu H, Zhang Y, Wang J. A proteomic analysis of seed development in Brassica campestri L. PLoS One. 2012;7:e50290. 
69. Corthals GL, Wasinger VC, Hochstrasser DF, Sanchez JC. The dynamic range of protein expression: a challenge for proteomic research. Electrophoresis. 2000;21:1104-15.

70. Gygi SP, Corthals GL, Zhang Y, Rochon Y, Aebersold R. Evaluation of twodimensional gel electrophoresis-based proteome analysis technology. Proc Natl Acad Sci U S A. 2000:97:9390-5.

71. Bradford MM. A dye-binding method for the determination of microgram quantities of protein. Anal Biochem. 1976;72:248-54.

72. Blum $H$, Beier $H$, Gross $H$. Improved silver staining of plant proteins, RNA and DNA in polyacrylamide gels. Electrophoresis. 1987;8:93-9.

73. GE Healthcare. 2-D electrophoresis: principles and methods. 2004

74. Carpentier SC, Witters E, Laukens K, Deckers P, Swennen R, Panis B.

Preparation of protein extracts from recalcitrant plant tissues: an evaluation of different methods for two-dimensional gel electrophoresis analysis. Proteomics. 2005:5:2497-507.

Submit your next manuscript to BioMed Central and we will help you at every step:

- We accept pre-submission inquiries

- Our selector tool helps you to find the most relevant journal

- We provide round the clock customer support

- Convenient online submission

- Thorough peer review

- Inclusion in PubMed and all major indexing services

- Maximum visibility for your research 